\title{
When Contractionary Fiscal Policy Is Expansionary
}

\author{
Tony Makin
}

$\mathrm{V}$ ERY early on, university students of economics absorb the Keynesian doctrine that fiscal stabilisation is central to macroeconomic policy management. Governments are supposed to use their discretionary spending and income-tax powers to smooth business cycle fluctuations for employment purposes. By altering economy-wide activity, fiscal stabilisation allegedly raises employment levels during recessions and curbs excessive aggregate expenditure and inflationary pressures during booms.

Although there are several well-known counterarguments to the Keynesian view of the macroeconomic impact of fiscal activism, it is still surprisingly popular among academic economists and remains influential in economic policy circles, in Australia and elsewhere. For instance, it has given the federal Treasury and successive Australian governments an intellectual, as well as an electoral, rationale for fiscal expansion, such as during the major recessions of the early 1980s and early 1990s.

Fiscal stabilisation is also frequently advocated in international policy circles. The most obvious example is Japan, where numerous budgetary measures have been implemented over recent years, often in response to international political pressures. These fiscal measures have been directly aimed at stimulating macroeconomic activity in the light of Japan's negligible economic growth throughout the 1990s. To date, however, Japanese fiscal activism has seemingly been to no avail.

Unrealistically, the textbook view of fiscal stabilisation affords no constructive, or reactive, role to financial markets. 'This simplistic view, promoted most fervently by the post-Keynesian school of macroeconomists, is also inadequately set within a redundant closed-economy framework and so fails to incorporate the effects of international capital flows, trade flows or exchange rate movements. As a consequence, this remarkably resilient paradigm can offer few insights into contemporary macroeconomic phenomena, such as the Asian economic crisis.

In this article, it is suggested that, like earlier non-Keynesian alternatives, fiscal activism can be counterproductive as a macroeconomic stabilisation tool under certain circumstances. As a corollary, it suggests that reducing public consumption expenditure in particular can have an expansionary impact on an economy that is highly integrated with international goods, services and asset markets. This pre-

Tony Makin is Associate Professor of Economics at The University of Queensland. 
scription is consistent with recent Australian and international evidence on the behaviour of key macroeconomic variables following episodes of fiscal consolidation.

\section{Old Crowding Out Counterarguments}

As currently expounded in textbooks, government expenditure can add directly to private sector spending on consumption and investment during cyclical troughs or subtract from aggregate spending during cyclical peaks. On the revenue side of the public accounts, discretionary changes to income taxes operate by varying first household disposable income and then aggregate expenditure. For instance, income tax cuts boost private sector consumption through a rise in household disposable income, which in turn lifts aggregate spending.

Interpreting the economy-wide impact of discretionary income tax changes is, however, much less straightforward than calculating spending changes, because households are likely to perceive tax changes as temporary rather than permanent. As well, there are supply-side complications associated with income tax changes that stem from possible work incentive effects. In what follows, the focus is therefore on the economy-wide effects of discretionary public spending changes.

The main arguments that have been mounted against fiscal stabilisation over the years, in both closed and open economy settings, have hinged on the offsetting behaviour of households and firms in response to budgetary shocks and fiscal deficits, as eventually reflected in private spending, interest rates and exchange rates. In one way or another, three quite different approaches predict that an increase in public spending will be offset by a fall in private spending, implying that higher public spending has no effect on the size of national income, at least in the short term. As a general rule, they each imply that government spending is more appropriately seen as a substitute for, rather than a complement to, private sector spending.

First, the Ricardian Equivalence proposition, the oldest non-Keynesian argument, suggests that forward-looking households should expect higher future taxes to follow rises in public spending when this spending is financed by running budget deficits and increased levels of public debt. Under these circumstances, households would save more today (that is, consume less) in anticipation of higher future tax rises that will become necessary when the public debt matures. In effect, this means that additional public spending 'crowds out' household consumption spending, leaving aggregate expenditure unchanged. Empirical evidence for a range of advanced economies suggests, however, that such offsetting spending behaviour by households has at most been partial. In other words, an extra dollar of public spending is matched by much less than a dollar of increased private saving.

Second, there is the standard 'investment crowding out' argument. This asserts that because higher government spending raises the public sector borrowing requirement, other things equal, it pushes up interest rates and thereby crowds out private sector investment spending. Hence, the pattern of expenditure shifts away from private investment towards government consumption. This implies that the

See Seater (1993) for a useful survey. 
opportunity cost of fiscal expansion is lower future economic growth, because the rate of real domestic capital accumulation falls.

Like the fundamental Keynesian model against which it was originally set, this proposition is severely limited by its closed-economy assumptions. The scale of international transactions has grown to such an extent that it is no longer appropriate to think about macrocconomic linkages without explicitly taking into account international factors such as foreign investment flows, current account deficits and exchange rates.

The most widely accepted theoretical approach to examining the impact of fiscal policy in the open economy is the model devised independently of one another by Mundell (1963) and Fleming (1962). 'This third, though still popular, approach predicts that if capital funds are highly mobile across borders and the exchange rate floats, then a rise in government spending will crowd out net exports by lowering exports and raising imports. In other words, under open-cconomy conditions, fiscal policy is ineffective as an income stabilisation tool, irrespective of the stage of the business cycle.

According to this model, higher public spending initially tends to push up the domestic interest rate; this induces foreign capital inflow, strengthens the nominal and real exchange rate and worsens competitiveness. The loss of competitiveness in turn lowers exports and raises imports, in the process also providing a theoretical rationale for the 'twin deficits' hypothesis. Hence, as with the two non-Keynesian arguments outlined above, fiscal policy is rendered impotent as a stabilisation tool because any rise in public spending simply offsets expenditure elsewhere, in this case on net exports. However, a major empirical problem for the Mundell-Fleming analysis is that the exchange rates of advanced economies have generally tended to appreciate rather than depreciate after periods of fiscal consolidation (as discussed further below).

\section{Taking International Investors' Reactions into Account}

A fundamental construction fault running through the Mundell-Fleming model is its presumption that aggregate production is essentially determined by total expenditure in the economy. In other words, it is a demand-side model, in which aggregate supply adjusts endogenously. This implies that national spending and national production are always equal in value. But international macroeconomic accounting dictates that trade and current account deficits can in principle arise only when aggregate output and aggregate expenditure are unequal, or (what amounts to the same thing) when domestic saving and investment differ.

In view of this, it is more appropriate to think about the effects of increased public spending by focusing on the direct theoretical links between higher public expenditure, domestic saving, the current account balance, foreign-investor reaction and the exchange rate. The following discussion outlines an alternative transmission mechanism for fiscal policy in the open economy consistent with a more formal model outlined in Makin (1998). 
The current account, inflation and exchange rate expectations. If public consumption increases, then the budget deficit will necessarily rise and domestic saving fall, if other things remain the same. This creates an additional financing requirement for the economy as aggregate spending outpaces aggregate production. With less domestic saving, there will be an increase in the demand for foreign funds to finance available domestic investment opportunities. However, what then becomes important is whether international capital markets consider the fiscally induced ex ante current account deficits attributable to the fall in domestic saving are sustainable. If these ex ante current account deficits are not sustainable, then the exchange rate must depreciate, as there would otherwise be an excess demand for foreign currency, or, equivalently, an excess supply of local currency in the foreign exchange market.

In other words, sustainability of a current account deficit stemming from fiscal expansion depends on whether foreign investors supply the extra funds necessary to finance the additional public spending by acquiring the Treasury bonds sold to fund the higher budget deficit. Yet foreigners will acquire domestic-currency denominated bonds issued at an interest rate in line with global interest rates only if they are sure that the exchange rate will not have depreciated by the time the bonds mature. This is because any future exchange rate depreciation would inflict capital losses on foreigners who hold domestic currency denominated bonds.

Foreign investors may quite rationally expect a depreciation because the extra current public spending adds only to the future demand for foreign currency when public debt repayments are due and not to the future supply of foreign currency through increased production in the cconomy. If this is the case, then the exchange rate will start to depreciate immediately. At the same time, domestic interest rates will be pushed above forcign interest ratcs, as the increased funding requirement remains and must be met from domestic saving. In theory, the extent of this domestic interest rate rise should also reflect the markets' expectations of exchange rate depreciation.

In the past, the monetary authorities of many economies have been tempted to monetise the stock of public debt arising from larger budget deficits in order to avoid tax rises to cover escalating public debt interest payments. When debt monetisation occurs, the accompanying rise in the domestic money supply subsequently fuels an economy's inflation rate. If international financial markets are concerned about future inflation risk as well, this would further raise their expectation of a later exchange rate depreciation.

When international financial markets expect the exchange rate to depreciate, there is likely to be an immediate capital ouflow to minimise future capital losses on existing domestic bond holdings. The ensuing currency depreciation thereby generates an immediate hike in domestic inflation rellecting price rises for imported goods and services. In contrast, the Mundell-Fleming model quite implausibly implies that more public spending has deflationary effects in the short term, because under floating exchange rates fiscal expansion in any form always appreciates the nominal exchange rate. 
Interestingly, a depreciating currency and higher domestic interest rates would have a similar macroeconomic effect as that proposed by the old investment crowding-out argument outlined earlier. Following fiscal expansion in the form of a public consumption increase, there would again be displaccment of domestic private sector investment and forgone economic growth, although in the open economy setting the crowding out results directly from the negative reaction of international capital markets.

Although usually espoused as an alternative means of fiscal transmission in the closed economy context, it is also still possible for Ricardian Equivalence to operate under open economy conditions. If there were a Ricardian effect following a rise in public spending in an open economy, then the resultant higher saving by residents, mindful of their future tax obligations, would reduce the external borrowing requirement. In the extreme though empirically unsupported case, if increased public consumption were matched dollar for dollar by a rise in domestic saving, this would make foreign borrowing unnecessary.

Comparing alternative theoretical perspectives. The following table summarises the differences between the various approaches to thinking about how discretionary increases in public spending affect key macroeconomic variables.

\section{Table 1}

\section{Effect of public spending increases on macroeconomic variables}

\begin{tabular}{lccccc}
\hline Theory & $\begin{array}{c}\text { Household } \\
\text { consumption }\end{array}$ & $\begin{array}{c}\text { Interest } \\
\text { rate }\end{array}$ & $\begin{array}{c}\text { National } \\
\text { income }\end{array}$ & $\begin{array}{c}\text { Exchange } \\
\text { rate }\end{array}$ & $\begin{array}{c}\text { Future } \\
\text { income }\end{array}$ \\
\hline $\begin{array}{l}\text { Keynesian } \\
\begin{array}{l}\text { Ricardian } \\
\text { equivalence }\end{array}\end{array}$ & $\uparrow$ & $\uparrow$ & $\uparrow$ & - & - \\
$\begin{array}{l}\text { Investment } \\
\text { crowding out }\end{array}$ & $\downarrow$ & 0 & 0 & - & 0 \\
$\begin{array}{l}\text { Mundell-Fleming } \\
\begin{array}{l}\text { Including reactive } \\
\text { foreign investors }\end{array}\end{array}$ & $\downarrow$ & $\uparrow$ & 0 & - & $\downarrow$ \\
\hline
\end{tabular}

This is not to say that all public expenditure increases are necessarily unproductive and that international capital markets will always judge them so. Importantly, the above-outlined transmission mechanism allowing for reactive foreign investors has assumed that fiscal expansion came in the form of a rise in public consumption. Alternatively, however, public investment may be increased which may well be sufficiently productive to meet with international investors' approval. In this case, a current account deficit arising from a discretionary increase in public investment may 
be sustainable, just as current account deficits attributable to higher private investment normally are. In other words, foreigners could conceivably fund additional public capital accumulation, without the economy suffering any attendant exchange rate and interest rate pressures, provided the public investment is considered to be sufficiently productive. For this reason, it is important that the economy's public accounts make a clear distinction between consumption and investment expenditure items on the outlays side.

Interestingly, if the fiscal authorities adhered to the so-called 'golden rule' of public finance, which states that public debt should be issued only to cover public investment and that public consumption spending should be met from taxation, there may be no adverse foreign investor reaction. Hence there may not be any exchange rate and interest rate effects, or any crowding out along the above explained lines. However, few governments have explicitly acknowledged or adhered to the golden rule, much less constitutionally codified it as a binding fiscal constraint. The fact remains that the overwhelming share of on-budget government spending is classified as consumption, which by definition yields no long-term economic benefits. Hence, it is understandable that international capital markets assume public expenditure increases are usually unproductive.

\section{The Expansionary Effects of Cutting Government Spending}

The theoretical discussion above has outlined the effects of discretionary increases rather than decreases in public spending, which is quite routine in economics textbooks. This textbook emphasis on spending increases essentially rellects the Keynesian habit of thinking that economies are more prone to recessions than to booms and hence more often warrant fiscal expansion. Moreover, over the terms of numerous business cycles, fiscal policy has not been practised in a symmetric way. Governments have usually raised public spending during cconomic downswings, but have later failed to scale spending back during upswings. Government spending in the OECD region as a whole rose from around 25 per cent of GDP in 1960 to over 40 per cent in 1996 (T/c Economist, 20 September 1997). Hence, substantial growth in public spending in advanced economies over the second half of the 20 th century has been another facet of the Keynesian legacy.

If increases in public spending tend to depreciate the exchange rate, push up domestic interest rates, lower investment and retard future income growth, then the opposite effects should be evident following cuts in unproductive public spending. That is, following fiscal consolidation involving cuts to public consumption, domestic saving should rise, interest rates fall, the exchange rate appreciate, investment rise and GDP improve.

Hence, the question of whether reducing public consumption will help or hinder economic performance becomes an empirical one. In this regard, the results of an International Monetary Fund (IMF) (1996:chs 3-5) study of fiscal consolidation episodes in advanced economies over recent decades are salutary. ${ }^{2}$ This study re-

${ }^{2}$ Sec also McDermott and Westcott (1996). 
vealed that reductions in public expenditure implemented over a minimum of two years generally improved macroeconomic performance. In particular, the IMF surveyed the impact of public expenditure cuts since the early 1980 s on key macrocconomic variables in OECD countries which experienced episodes of fiscal consolidation. These countries included Australia, Belgium, Denmark, Ireland, Japan, New Zealand, Norway, Sweden and the United States. In the two-year adjustment phase following the public expenditure cuts, domestic interest rates fell and exchange rates strengthened in these economies, consistent with the alternative transmission mechanism proposed above. Moreover, in economies where expenditure cuts reduced budget deficits by over 1.5 per cent of GDP, there was a fillip to GDP growth for up to two years afterwards. The fiscal consolidation episodes in Denmark in the mid-1980s and in Ireland in the late 1990s were especially successful.

\section{Figure 1}

\section{Public consumption and public investment as percentages of GDP, Australia 1970-95}

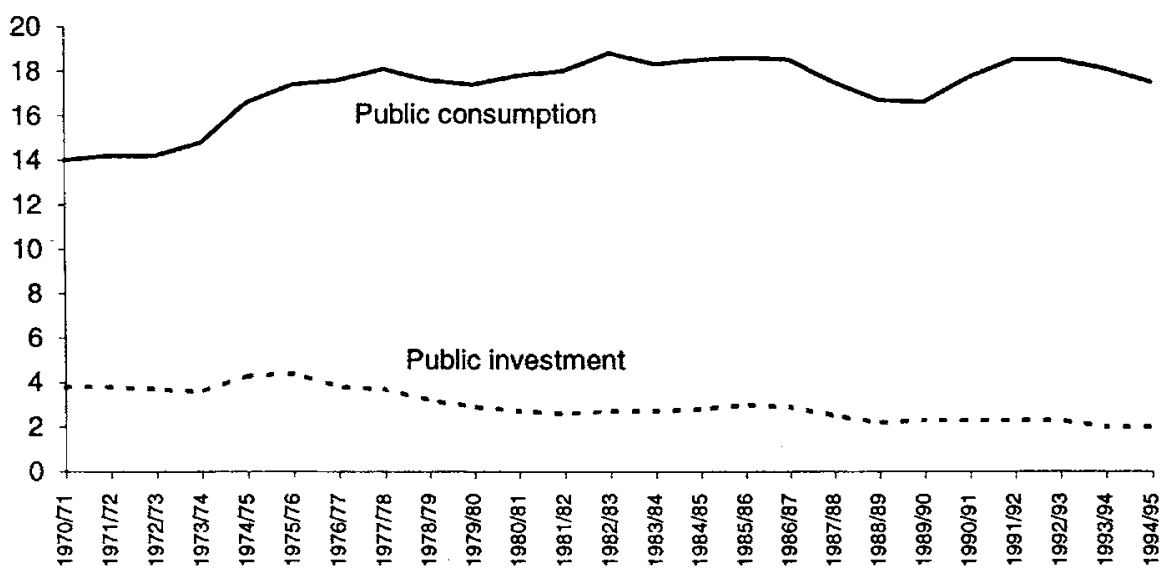

Source: Reserve Bank of Australia (1996).

In Australia's case, it is noteworthy that significant changes in the share of public consumption are often associated with opposite changes in the share of private investment. For instance, the sharp rise in the share of public consumption in the 1970s coincided with a fall in private investment. Closed-economy Keynesian economics probably reached its high water mark in policy circles at this time. Not coincidentally, the $1970 \mathrm{~s}$ is easily the worst decade for economic performance in the second half of the 20th century in terms of inflation and growth outcomes. In the late 1980 s, fiscal consolidation actually sparked a strong rise in private investment and subsequent economic boom. 


\section{Conclusion}

To be plausible, macroeconomic theories have to be based on assumptions that reflect contemporary conditions and also have to be capable of explaining recent historical episodes. Any model that purports to explain the operation of fiscal policy in increasingly globalised economies therefore requires an approach which is explicitly founded on open-economy linkages and which yields predictions that fit reality.

Contrary to the Keynesian idea that tight fiscal policy can depress an economy's performance, there are theoretical and empirical grounds for believing that bouts of fiscal consolidation actually improve macroeconomic performance by eventually accelerating investment and GDP growth. This is exactly what has happened following a number of fiscal consolidation episodes in many advanced economies over recent decades. However, it critically depends on whether the reduced government spending is in the nature of consumption or investment.

Fiscal policy is likely to be expansionary when it contracts public consumption expenditure in an open economy. In essence, the argument is that a positive reaction from foreign investors to reduced public consumption, easily the largest component of total public spending, would tend to lower domestic interest rates and thus stimulate increased private domestic investment in an open economy. On the other hand, it is still possible under current conditions for fiscal policy involving increased public investment to be expansionary, provided foreign investors judge the additional public investment expenditure to be productive.

The above discussion suggests that the macroeconomic terminology that is widely used to describe changes in the stance of fiscal policy is often misleading. For instance, fiscal 'expansion' or, worse, fiscal 'stimulus' does not imply higher overall economic activity, if it stems from a rise in government consumption. On the other hand, fiscal consolidation that targets unproductive spending is likely to be expansionary for the economy.

\section{References}

Fleming, J. (1962), 'Domestic Financial Policy Under Fixed and Floating Exchangc Rates', IMF Staff Papers 9: 369-79.

Intennational Monetary Fund (IMF) (1996), World Eronomic Outlook, Washington DC.

McDermott, C. \& R. Westcott (1996), 'Fiscal Reforms That Work', Economic Issues 4, International Monetary Fund, Washington DC.

Makin, A. (1998), 'A Dependent Economy Morlel of Public Expenditure and the Exchange Rate', International Review of Economics and Finance (forthcoming).

Mundell, R. (1963), 'Capital Mobility and Stabilisation Policy Under Fixed and Flexible Exchange Rates', Canadian Jounal of Economics and Political Science 29: 475-85.

Reserve Bank of Australia (1996), Australian Economic Statistics 1949-50 to 1994-95, Sydney (Occasional Paper No. 8).

Seater, J. (1993), 'Ricardian Equivalence', Jounal of Economic Literature 31: 142-90.

The author thanks an anonymous referee and the editor for useful comments. 